\title{
B10 Cells Ameliorate the Progression of Lupus Nephritis by Attenuating Glomerular Endothelial Cell Injury
}

\author{
Miao Yu $u^{a}$ You Song ${ }^{b}$ Ming-Xin Zhu ${ }^{a}$ Wei Liang ${ }^{a}$ Qi Long ${ }^{a}$ Pei-Wu Ding ${ }^{a}$ Yu Xie ${ }^{a}$ \\ Yu-Hua Liao a Jing Yuan ${ }^{a}$ \\ aLaboratory of Cardiovascular Immunology, Institute of Cardiology, Union Hospital, Tongji Medical \\ College, Huazhong University of Science and Technology, Wuhan, bepartment of Rheumatology, \\ Union Hospital, Tongji Medical College, Huazhong University of Science and Technology, Wuhan, China
}

\section{Key Words}

Lupus nephritis • B10 cells • IL-10 • Glomerular endothelial cell

\begin{abstract}
Background/Aim: B10 cells are generally considered to inhibit the kidney injury in systemic lupus erythematosus (SLE) mouse models, but recently this function of B10 cells was denied by the lineage-specific deletion of IL-10 from B cells. Thus, this study aimed to determine whether and how B10 cells play a protective role in lupus nephritis (LN). Methods: LN and non-LN SLE patients without receiving any treatments were recruited, and the percentages of circulating B10 cell were determined. Furthermore, the purified B10 cells were transferred into MRL/lpr SLE mice, and the exact effects of B10 cells on LN progression were investigated. Results: The percentage of circulating B10 cells was significantly higher in patient than in healthy controls, while they were fewer in LN patients than non-LN SLE patients. Moreover, B10 cells rather than plasma IL-10 levels were negatively correlated with disease severity especially with kidney injury in LN patients. In animal experiments, the glomerular injuries including the proteinuria and pathological scores were significantly attenuated in SLE mice transferred with B10 cells, accompanied by the decreased glomerular endothelial cell CD54/CD106 expression, and glomerular p38 phosphorylation as well as increased SOCS3 expression. At the same time, the serum anti-dsDNA autoantibody, TNF- $\alpha$ and IFN- $\gamma$ levels were also reduced, while there were no changes in serum IL-10 and IL-17 levels in B10 cell transferred mice. Conclusion: These findings suggest that B10 cells could - independent from IL-10 - ameliorate glomerular injury in LN through protection of glomerular endothelial cells.
\end{abstract}




\section{Cellular Physiology Cell Physiol Biochem 2015;36:2161-2169 \begin{tabular}{l|l} 
and Biochemistry Published online: July 21, 2015 & $\begin{array}{l}\text { C 2015 S. Karger AG, Basel } \\
\text { www.karger.com/cpb }\end{array}$ \\
\hline
\end{tabular} \\ Yu et al.: B10 Cells Inhibit Glomerular Endothelial Cell Activation}

\section{Introduction}

Lupus nephritis (LN) is a major cause of morbidity and mortality in systemic lupus erythematosus (SLE) [1]. In recent years, despite the therapeutic approach have been improved, many patients with LN eventually progress to end-stage renal disease [2].

The most common pathologic feature in LN is the glomerular injury accompanied by proteinuria [3]. B cells are involved in the development of LN through localized autoantibody generation, proinflammatory cytokine production, and effector leukocytes chemotaxis [48]. Recently, Wang et al proved that the $\mathrm{CD} 19^{+} \mathrm{CD} 5^{+} \mathrm{CD} 1 \mathrm{~d}^{\text {high }} \mathrm{IL}-10$-secreting B cells (B10 cells) were negatively correlated with disease activity in patients with IgA nephropathy [9]. Furthermore, Tedder et al found that B10 cells could attenuate the LN injuries in NZB/W SLE mice $[10,11]$. These immunosuppressive effects of B10 cells then provided more evidence for the pleiotropic functions of B cells in immune-mediated kidney damages. However, Teichmann et al lately announced that B10 cells could not regulate systemic autoimmunity in MRL/lpr SLE mice by lineage-specific deletion of IL-10 from B cells [12]. Thus, further investigations were needed to determine whether and how B10 play a protective role in LN.

In this study, we firstly investigated the accurate expressions of B10 cells in SLE patients with LN and found that B10 cells were negatively correlated with disease severity especially with the glomerular injury. To explore the effects and mechanisms of B10 cells on the progressions of LN, we transferred the purified B10 cells into MRL/lpr mice, and found B10 cells indeed ameliorated glomerular injures by inhibiting glomerular endothelial cell abnormal activation through depressing P38 phosphorylation.

\section{Materials and Methods}

\section{Patients and blood samples}

A total of forty-six newly diagnosed SLE patients according to the American College of Rheumatology revised classification criteria for lupus [13] were recruited from Union Hospital, Tongji Medical College, Huazhong University of Science and Technology from August 2012 to May 2014. All of these patients had active SLE, which were assessed with American Systemic lupus Erythematosis Disease Activity Index (SLEDAI) [14]. Fourteen age and sex-matched healthy volunteers were included as the healthy controls. This study was conformed to the guidelines of Helsinki declaration and its amendments and got the approval of the ethics committee of Tongji Medical College, Huazhong University of Science and Technology, China. All participators were recruited after obtaining informed consent. Morning fasting blood samples were collected from all of the participants before any treatment. The blood sample was centrifuged at $2000 \mathrm{rpm}$ for $15 \mathrm{~min}$, the plasma was stored at $-20^{\circ} \mathrm{C}$ for further measurements, and the cells in the blood were layered over Ficoll-Hypaque density gradient solution to isolate peripheral blood mononuclear cells (PBMCs).

Animals

Female MRL/lpr mice with spontaneous SLE aged 10 weeks were purchased from the experimental animal centre of Chinese Academy of Science (Shanghai, China). All animals were kept in the pathogen-free mouse room in the experimental animal centre (Tongji Medical College of Huazhong University of Science and Technology). The animal experiments were carried out according to the guidelines for the Care and Use of Laboratory Animals (Health Department of Huibei Province, PR China, 2005) and the guidelines of the Laboratory Animal Ethical Commission of Tongji Medical College of Huazhong University of Science and Technology.

Interventions and groups

The MRL/lpr mice were separated randomly into three groups and given different interventions at 12 weeks of age: (1) SLE group: mice were administered with saline (100ul per mouse, n=10); (2) B10 group: mice were injected with B10 cells $\left(2 \times 10^{6}\right.$ in 100 ul saline per mouse, $\left.n=10\right)$; and (3) Bcon group: mice were injected with non-IL-10-secreting B cells $\left(2 \times 10^{6}\right.$ in 100 ul saline per mouse, $\left.n=10\right)$. Serum was separated from blood collected via retro-orbital bleeding and the urine was gathered in the early morning once every 


\section{Cellular Physiology Cell Physiol Biochem 2015;36:2161-2169 \begin{tabular}{l|l} 
and Biochemistry Published online: July 21, 2015 & $\begin{array}{l}\text { C 2015 S. Karger AG, Basel } \\
\text { www.karger.com/cpb }\end{array}$ \\
\hline
\end{tabular} \\ Yu et al.: B10 Cells Inhibit Glomerular Endothelial Cell Activation}

four weeks. These specimens were stored at $-80^{\circ} \mathrm{C}$ for the following measurements. Animals of each group were killed at 40 weeks of age, and their kidneys were removed freshly for the hematoxylin and eosin (H\&E), immunohistochemistry and western blot examination. The spleens were isolated aseptically to prepare the mononuclear cell suspensions for the flow cytometry.

\section{Isolation and adoptive transfer of B10 cells}

The mononuclear cell suspensions from the spleen of 12-week-old C57BL/6 mice were prepared and harvested. Then the B10 cells were purified using Regulatory B Cell Isolation Kit (Miltenyi Biotech) from the single cell suspensions. After isolation, these B10 cells with the purities of over 85\% were transferred into 12-wk-old MRL/lpr mice through the vein in tail. And the B cells that did not secret IL-10 were adoptive transferred as the control.

\section{ELISA}

The cytokines including plasma IL-10 from SLE patients and healthy volunteers, serum IL-10, IL-17, TNF- $\alpha$ and IFN- $\gamma$ from MRL/lpr mice were examined by different ELISA kits according to the manufacturer's instructions. The sensitivity of human IL-10 ELISA kit (eBioscience) was $0.05 \mathrm{pg} / \mathrm{ml}$, and they were 15 $\mathrm{pg} / \mathrm{ml}, 7 \mathrm{pg} / \mathrm{ml}, 8 \mathrm{pg} / \mathrm{ml}$, and $7 \mathrm{pg} / \mathrm{ml}$ for mouse IL-10, IL-17, TNF- $\alpha$ and IFN- $\gamma$ ELISA kits (neobioscience) respectively. There was no cross-reactivity observed in detection. All samples were measured in triplicate.

The levels of anti-dsDNA autoantibody in mouse sera were also determined with the ELISA kit (ADI) following the manufacturer's protocols. The sensitivity of this ELISA kit was optimized with serum samples diluted 1:100 and there was no cross-reactivity detected. All samples were measured in triplicate.

\section{Flow cytometry}

The PBMCs from SLE patients and healthy volunteers were harvested and stained with fluorescein isothiocyanate (FITC)-labeled anti-human CD19, phycoerythrin (PE)-labeled anti-human CD1d and allophycocyanin (APC)-labeled anti-human CD5 antibodies (Biolegend). After washing, the cells were resuspended at a density of $2 \times 10^{6} / \mathrm{ml}$ and stimulated with PMA (100 ng / ml), ionomycin (1 ug / ml) and monensin ( $1 \mathrm{ug} / \mathrm{ml}$ ) at $37^{\circ} \mathrm{C}, 5 \% \mathrm{CO}_{2}$ of a 24-well culture plate (Corning) in RPMI 1640 medium (Gibco) supplemented with $100 \mathrm{U} / \mathrm{ml}$ penicillin, $100 \mathrm{ug} / \mathrm{ml}$ streptomycin, and $10 \%$ fetal bovine serum (FCS, Gibco). After $5 \mathrm{~h}$, the cells were fixed, permeabilized and stained intracellularly at $4^{\circ} \mathrm{C}$ for $30 \mathrm{~min}$ with PECy7-labeled anti-human IL-10 antibody (Biolegend). Meanwhile, the isotype controls were given to regulate compensation and confirm antibody specificity. Samples were acquired and analyzed with a FACSCalibur (BD Biosciences).

\section{Biochemical assay}

The urinary protein concentration at 12, 16, 20, 24, 28, 32, and 36 weeks of age from MRL/lpr mice were tested with Bradford method using the Coomassie plus (Bradford) assay kit (Thermo). The bovine serum albumin (BSA) was used as the standard. The working range is $100-1500 \mathrm{ug} / \mathrm{ml}$.

\section{Histopathology}

The kidneys at 40 weeks of age from MRL/lpr mice were fixed in $10 \%$ phosphate-buffered formalin, trimmed and embedded routinely in paraffin. The $5 \mu \mathrm{m}$ sections were cut longitudinally and stained with H\&E. The severity of glomerular impairment in H\&E section was scored by two independent researchers separately in a blinded manner as 0 , no significant findings; 1 , minimal; 2, mild; 3, moderate; or 4, severe, as previously described by Olympus bh2 microscope [15].

\section{Immunohistochemistry}

The kidney tissue was paraffin-embedded and cut into $5 \mu \mathrm{m}$ sections. The sections were heated by microwave in $0.01 \%$ citrate buffer $(\mathrm{PH}=9.0)$ and then treated with $3 \% \mathrm{H}_{2} \mathrm{O}_{2}$ for 10 min to inhibit endogenous peroxidase activity. After washing with PBS buffer three times and blocking with 3\% bovine serum albumin (BSA) for $30 \mathrm{~min}$, these sections were incubated with rat anti-mouse IgG, CD54 and CD106 antibodies (eBioscience) at $4{ }^{\circ} \mathrm{C}$ overnight and then washed with PBS buffer three times. After incubating with HRP-conjugated anti-rat antibody (Invitrogen) for $45 \mathrm{~min}$, the sections were washed. Finally, the diaminobenzidine solution was added, and the sections were counterstained by hematoxylin. 


\section{Cellular Physiology Cell Physiol Biochem 2015;36:2161-2169 \begin{tabular}{l|l|l}
\hline DOI: 10.1159/000430182 & (C) 2015 S. Karger AG, Basel
\end{tabular} www.karger.com/cpb \\ Yu et al.: B10 Cells Inhibit Glomerular Endothelial Cell Activation}

\section{Western blot}

The glomeruli were isolated from MRL/lpr mice by differential sieving as previously described [16]. The total proteins from the glomeruli were extracted with total protein extraction kit (Pierce) and samples containing $50 \mu \mathrm{g}$ proteins were separated and electrotransferred onto nitrocellulose membranes. The membranes were blocked in TBST containing $5 \%$ skim milk and incubated with primary antibodies against mouse total (t)-P38 (1:1000, Cell Signaling Technology), phosphor (p)-P38 (1:500, Cell Signaling Technology), SOCS3 (1:1000, Cell Signaling Technology), and $\beta$-actin (1:1000, Cell Signaling Technology) at $4{ }^{\circ} \mathrm{C}$ overnight. After incubating with horseradish peroxidase-conjugated secondary antibody (1:3000, $37^{\circ} \mathrm{C}, 2 \mathrm{~h}$ ), the target bands were washed and developed with ECL reagent (Thermo). The results were semiquantitatively analyzed using densitometric methods.

\section{Statistical analysis}

Data were shown as the mean \pm SEM. Statistical analysis was performed with 2-tailed Student's t test (two groups) or one-way ANOVA (more than two groups), and the correlation between two variables was tested by bivariate correlation analysis by SPSS11.0. $\mathrm{P}<0.05$ was considered as statistically significant.

\section{Results}

Circulating B10 cells and IL-10 levels in SLE patients

The percentages of circulating $\mathrm{CD} 19^{+} \mathrm{CD}^{+} \mathrm{CD} 1 \mathrm{~d}^{\text {high }}$ IL-10-secreting B10 cells were significantly increased in LN $(\mathrm{p}<0.01)$ and non-LN SLE $(\mathrm{p}<0.01)$ patients compared to healthy controls. Meanwhile, the levels of circulating B10 cells in LN group were lower than those in non-LN SLE patients ( $p<0.01$, Fig. $1 \mathrm{~A}$ and $\mathrm{B}$ ).

The levels of serum IL-10 were also found elevated in LN and non-LN SLE patients compared to healthy controls (all $\mathrm{p}<0.05$ ). However, there was no significant difference in IL-10 levels between non-LN SLE and LN patients (Fig. 1C).

The relationship between $B 10$ cells and the disease severities of LN patients

The clinical data of LN and non-LN SLE patients were listed in Table 1. Compared with the non-LN SLE patients, LN patients represented significant increased levels of SLEDAI ( $p=0.007)$, white blood cell ( $\mathrm{p}=0.042)$, creatinine $(p=0.021), 24 \mathrm{~h}$ urine protein $\quad(\mathrm{P}<0.001)$, urinary albumin $\quad(p=0.001)$. Moreover, the numbers of red blood cell $(p=0.034)$ in $L N$ patients were obviously lower than those in non-LN SLE patients. There were no significant differences in age $(p=0.477)$ and sex $(p=0.868)$ between LN and non-LN SLE patients (Table 1).

We performed correlation analysis for B10 percentages and disease severities of LN patients. It showed that B10 percentages
Table 1. The basic clinical features. Values are means \pm SEM

\begin{tabular}{lllc}
\hline & LN (n=26) & non-LN SLE (n=20) & p-value \\
\hline Age (year) & $38 \pm 3$ & $37 \pm 2$ & 0.477 \\
Sex (male / female) & $3 / 23$ & $2 / 18$ & 0.868 \\
SLEDAI & $19.8 \pm 2.2$ & $13.0 \pm 1.0$ & 0.007 \\
Red blood cell (T/L) & $3.3 \pm 0.2$ & $3.7 \pm 0.1$ & 0.034 \\
White blood cell (G/L) & $3.6 \pm 0.6$ & $2.6 \pm 0.3$ & 0.042 \\
Platelet (G/L) & $129.0 \pm 24.0$ & $120.0 \pm 22.5$ & 0.743 \\
ALT (U/L) & $32.7 \pm 9.6$ & $30.8 \pm 2.4$ & 0.858 \\
AST (U/L) & $46.7 \pm 9.5$ & $40.1 \pm 3.3$ & 0.351 \\
Urea nitrogen (mmol/L) & $5.1 \pm 0.8$ & $3.6 \pm 0.5$ & 0.085 \\
Creatinine (umol/L) & $60.9 \pm 7.8$ & $47.1 \pm 2.1$ & 0.021 \\
hs-CRP (mg/L) & $4.9 \pm 1.0$ & $4.8 \pm 1.1$ & 0.947 \\
ESR (mm/h) & $62.7 \pm 9.3$ & $46.5 \pm 7.9$ & 0.151 \\
C3 (g/L) & $0.4 \pm 0.1$ & $0.6 \pm 0.1$ & 0.062 \\
IgG (g/L) & $23.7 \pm 2.5$ & $19.4 \pm 1.9$ & 0.140 \\
ANA (+/-) & $25 / 1$ & $19 / 1$ & 0.849 \\
Anti-dsDNA Ab (+/-) & $17 / 9$ & $10 / 10$ & 0.293 \\
Anti-Sm Ab (+/-) & $12 / 14$ & $8 / 12$ & 0.676 \\
24h urine protein (mg) & $1282.0 \pm 433.0$ & $146.0 \pm 18.9$ & $<0.001$ \\
Urinary albumin (mg/L) & $350.0 \pm 135.0$ & $8.6 \pm 1.6$ & 0.001 \\
\hline & & &
\end{tabular}




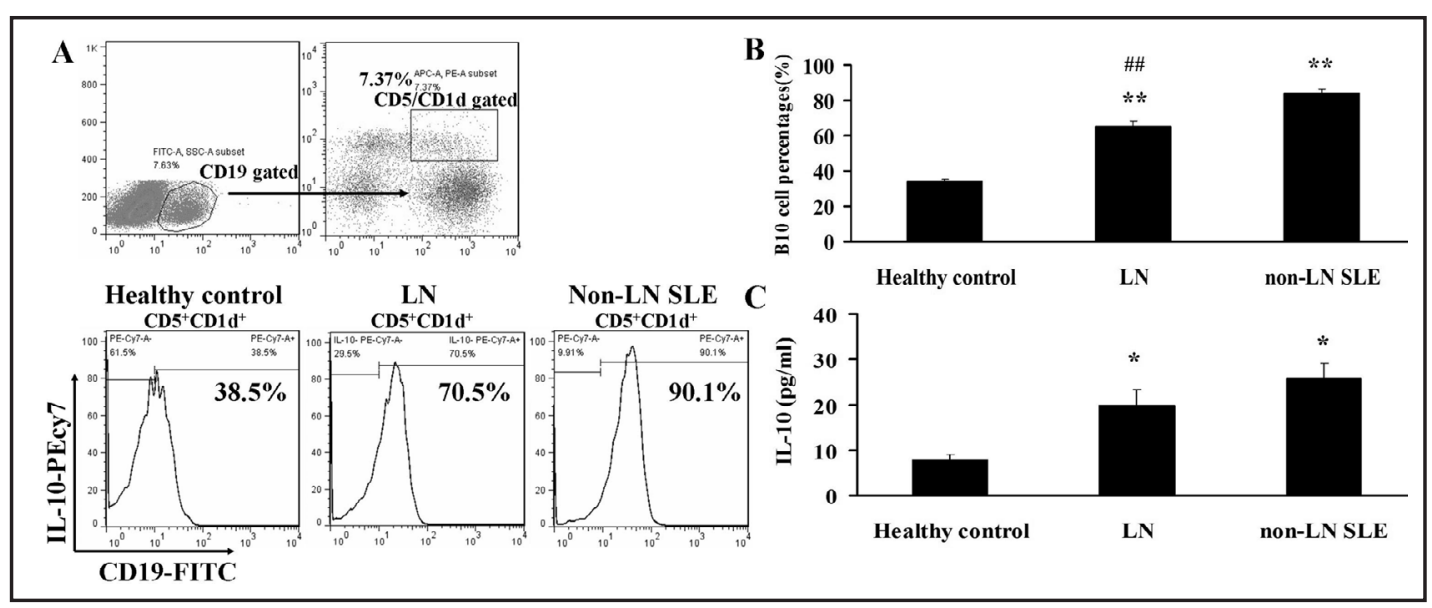

Fig. 1. Circulating B10 cells and IL-10 levels in SLE patients. (A) The representative pictures for CD19+ $\mathrm{CD}^{+} \mathrm{CD} 1 \mathrm{~d}^{+} \mathrm{IL}-10^{+} \mathrm{B} 10$ cells in each group by flow cytometry. The CD19+IL-10+ cell percentages were gated in $\mathrm{CD}^{+} \mathrm{CD} 1 \mathrm{~d}^{+}$cells (B) The results of statistical analysis for the percentages of B10 cells in each group. **, $\mathrm{p}<0.01$ vs Healthy control group. \#\#, $\mathrm{p}<0.01$ vs Non-LN SLE group. Values are means \pm SEM.

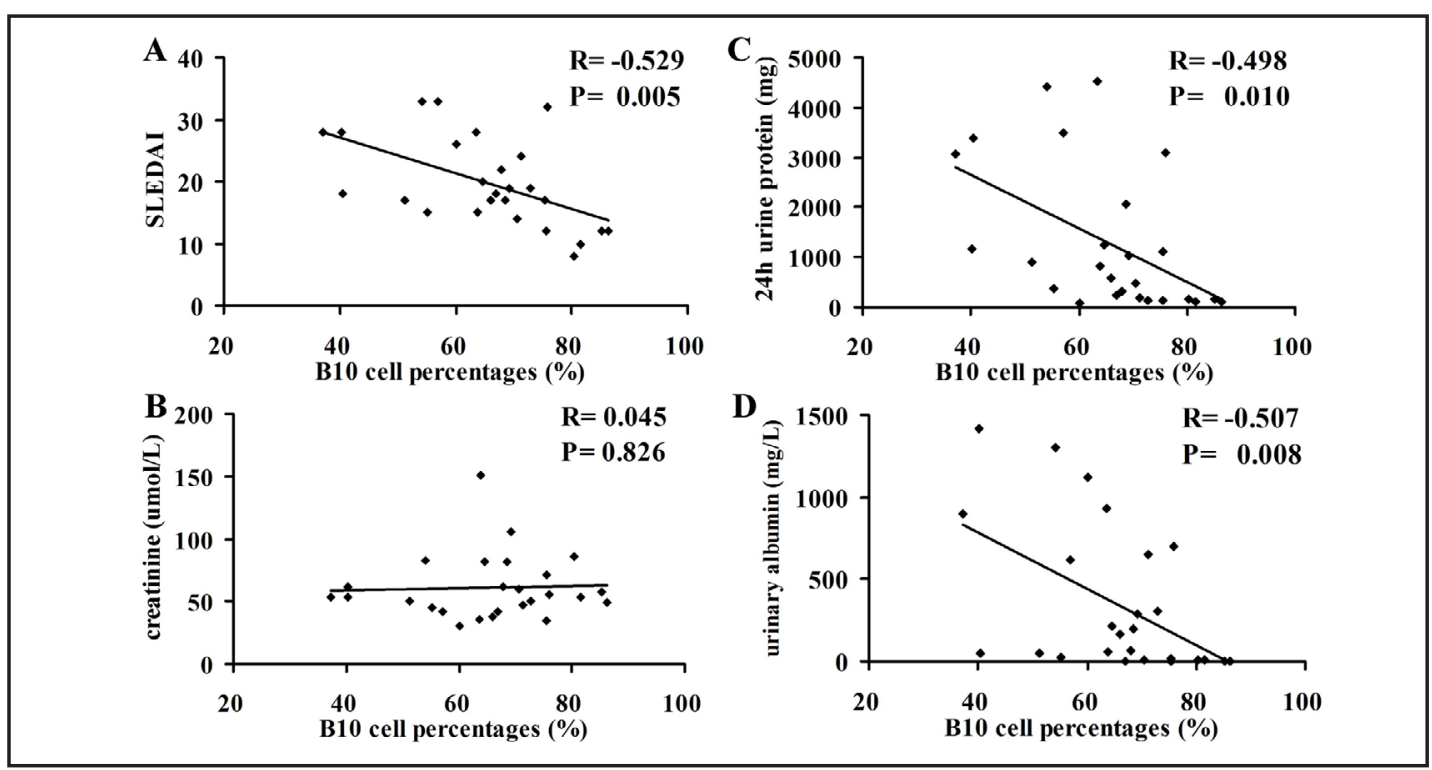

Fig. 2. The relationship between B10 cells and the disease severities of LN patients. (A) The correlation analysis of B10 percentages and Systemic lupus Erythematosis Disease Activity Index (SLEDAI) in LN patients, the correlation index (R) is $-0.529, p=0.005$. (B) The correlation analysis of B10 percentages and serum creatinine levels in LN patients, the correlation index $(R)$ is $0.045, p=0.826$. (C) The correlation analysis of B10 percentages and $24 \mathrm{~h}$ urine protein levels in LN patients, the correlation index (R) is $-0.498, p=0.010$.

(D) The correlation analysis of B10 percentages and urinary albumin in LN patients, the correlation index (R) is $-0.507, \mathrm{p}=0.008$.

were negatively correlated with the levels of SLEDAI $(\mathrm{R}=-0.529, \mathrm{p}=0.005), 24 \mathrm{~h}$ urine protein $(\mathrm{R}=-0.498, \mathrm{p}=0.010)$, and urinary albumin $(\mathrm{R}=-0.507, \mathrm{p}=0.008)$ in $\mathrm{LN}$ patients. However, there was no obvious correlation between B10 cell frequencies and serum creatinine levels in $\mathrm{LN}$ patients $(\mathrm{R}=0.045, \mathrm{p}=0.826$, Fig. $2 \mathrm{~A}-\mathrm{D})$. In addition, there were no direct correlations between B10 cells and the levels of SLEDAI $(\mathrm{R}=-0.138, \mathrm{p}=0.563), 24 \mathrm{~h}$ urine protein $(\mathrm{R}=-$ $0.151, p=0.524)$, urinary albumin $(R=-0.345, p=0.137)$, and serum creatinine $(R=-0.238$, $\mathrm{p}=0.311$ ) levels in non-LN SLE patients. The serum IL-10 levels were also not correlated with SLEDAI $(\mathrm{R}=-0.231, \mathrm{p}=0.256), 24 \mathrm{~h}$ urine protein $(\mathrm{R}=-0.356, \mathrm{p}=0.075)$, urinary albumin 


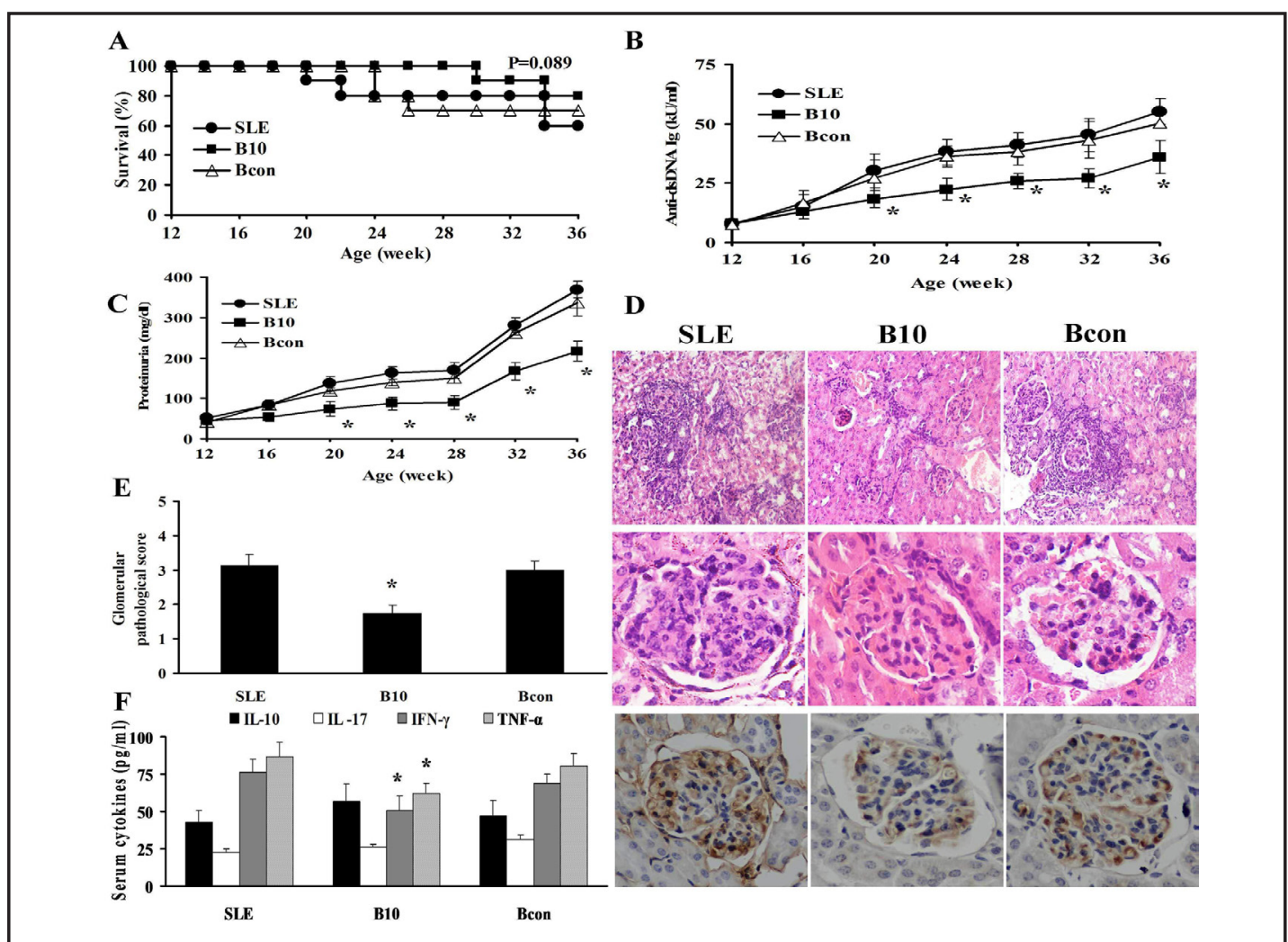

Fig. 3. Adoptive transfer of B10 cells attenuated the progression of lupus nephritis in MRL/lpr mice. (A) The survival rates in different groups monitored every four weeks. (B) The levels of serum anti-dsDNA autoantibodies in different groups at 12, 16, 20, 24, 28, 32 and 36 weeks of age. (C) The levels of proteinuria in different groups at 12,16,20,24, 28, 32 and 36 weeks of age. (D) The representative pictures of histopathology (upper, magnification $\times 200$, middle, magnification $\times 400$ ), and IgG deposition (lower, magnification $\times 400$ ) at 40 week of age. (E) The glomerular pathological scores in different groups at 40 week of age. (F) The levels of serum TNF- $\alpha$, IFN- $\gamma$, IL-10 and IL-17 levels at 40 week of age. *, p<0.05 vs SLE and Bcon groups. Values are means \pm SEM.

$(R=-0.145, p=0.481)$, and serum creatinine $(R=-0.140, p=0.495)$ levels in these LN patients respectively.

Adoptive transfer of B10 cells attenuated the progression of lupus nephritis in MRL/lpr mice

To further evaluate the effects of B10 cells on the renal injury in LN, the adoptive transfer of B10 cells was carried out in MRL/lpr mice. We found that the death of mice in B10 group started at 30 weeks of age, which was evidently later than SLE group at 20 weeks old and the Bcon group at 24 weeks old. However, the survival rate presented no differences among these three groups before the end of the experiment (Fig. 3A).

The levels of anti-dsDNA autoantibodies in B10 group were obviously lower than SLE and Bcon groups at 20,24,28,32, and 36 weeks of age (all $p<0.05$, Fig. 3B). And the similar significant changes were also observed in the parameters for the renal injury such as the levels of urine protein and the pathological scores of glomeruli (all $\mathrm{p}<0.05$, Fig. 3C-E). And the IgG deposition in glomeruli was also reduced in B10 group compared with those in SLE and Bcon groups (Fig. 3D).

The levels of serum TNF- $\alpha$ and IFN- $\gamma$ levels were significantly deceased $(p<0.05)$, while there were no changes in serum IL-10 and IL-17 levels in B10 group compared with those in SLE and Bcon groups at 40 week of age (Fig. 3F). In addition, there were no significant differences in these parameters between SLE and Bcon groups. 


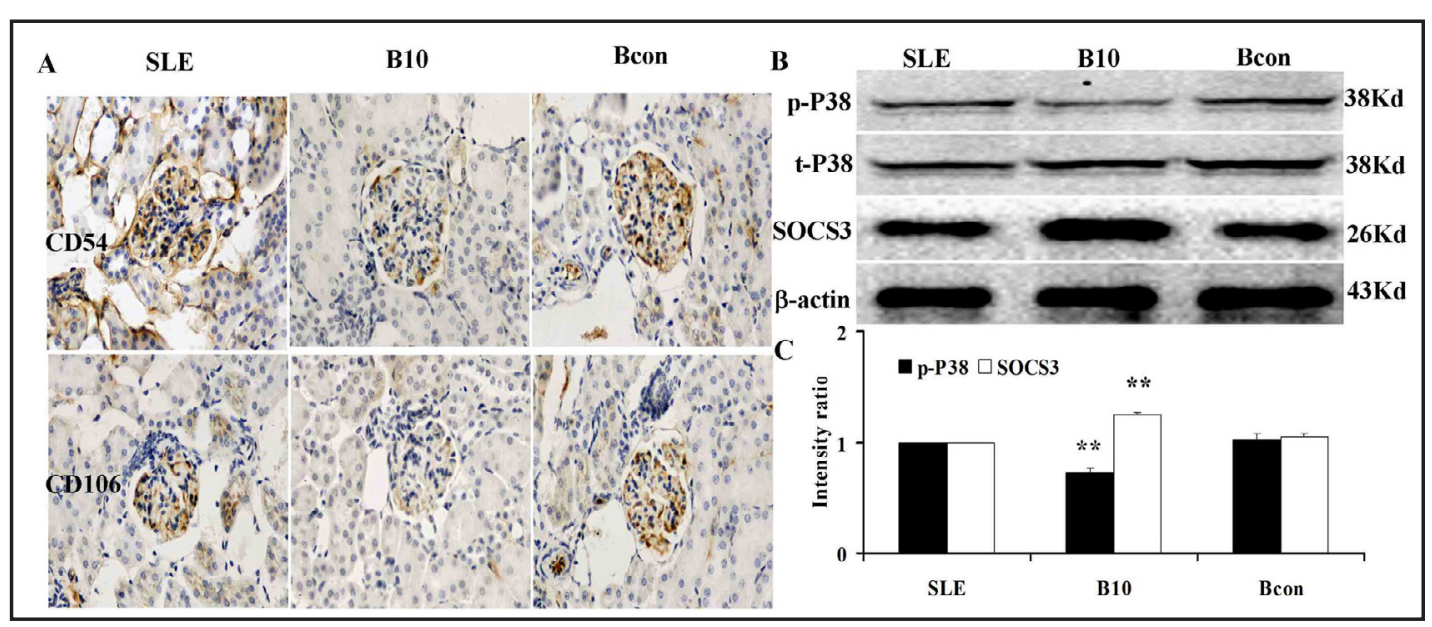

Fig. 4. B10 cells alleviated glomerular endothelial cell injuries in MRL/lpr mice. (A) The representative immunohistochemical pictures of CD54 and CD106 expressions in glomeruli (magnification $\times 400$ ). (B) The representative pictures of p-P38, t-P38, and SCOS3 expressions in glomeruli. (C) The results of statistical analysis for the protein levels of p-P38, t-P38, and SCOS3 in glomeruli. **, $\mathrm{p}<0.01$ vs SLE and Bcon groups. Values are means \pm SEM.

\section{B10 cells alleviated glomerular endothelial cell injuries in MRL/lpr mice}

To clarify the protective roles of B10 cells in the kidney, we investigated the injuries of the glomerular endothelial cells in MRL/lpr mice from different groups. The data represented that the expressions of CD54 and CD106 on glomerular endothelial cells were all obviously declined in B10 group compared with those in SLE and Bcon groups (Fig. 4A). Keeping in line with these alterations, the p-P38 protein levels in purified glomeruli were also significantly lower in B10 group than those in SLE and Bcon groups, but the SCOS3 levels in glomeruli showed the opposite changes ( $p<0.05$, Fig. $4 \mathrm{~B}$ and $\mathrm{C}$ ). All of these measurements displayed no significant differences between SLE and Bcon groups.

\section{Discussion}

Although $\mathrm{CD} 19^{+} \mathrm{CD}^{+} \mathrm{CD} 1 \mathrm{~d}^{\text {high }}$ IL-10-secreting B10 cells have been known as the main regulatory $\mathrm{B}$ cells in mice, $\mathrm{CD} 19^{+} \mathrm{CD} 24^{\mathrm{hi}} \mathrm{CD} 38^{\text {hi }}$ cells are generally taken as the dominant IL-10 producing regulatory B cells in human [17]. Recently, Yang et al have proved that CD19 ${ }^{+} \mathrm{CD}^{+} \mathrm{CD} 1 \mathrm{~d}^{\text {high }} \mathrm{B}$ cells are also exist in human, and the percentages of these cells are elevated in SLE patients undergoing some sort of immunosuppressive treatments [18]. However, their detection was $\mathrm{CD} 19^{+} \mathrm{CD}^{+} \mathrm{CD} 1 \mathrm{~d}^{\text {high }} \mathrm{B}$ cells but not $\mathrm{CD} 19^{+} \mathrm{CD} 5^{+} \mathrm{CD} 1 \mathrm{~d}^{\text {high }} \mathrm{IL}-10$ secreting B cells. In this study, we investigated the CD $19^{+} \mathrm{CD} 5^{+} \mathrm{CD} 1 \mathrm{~d}^{\text {high }} \mathrm{IL}-10$-secreting $\mathrm{B} 10$ cell expressions in newly diagnosed SLE patients before any treatment, and found that B10 cells were indeed increased significantly in these patients. At the same time, the percentages of B10 cells in patients with LN were obviously lower than those in non-LN SLE patients. Moreover, these cells were negatively correlated with the severity of LN including the increased levels of SLEDAI, 24h urine protein, and urinary albumin. Howie et al considered that creatinine was an indirect measure of renal function and an unnecessary predictor of long-term renal outcome in $\operatorname{LN}[19,20]$. Herein, we also proved that there was no significant correlation between the levels of B10 cells and creatinine in LN patients. By using adoptive transfer, B10 cells were also observed to improve the damages of the disease, especially the renal injuries in MRL/lpr mice with spontaneous SLE. These clinical and experimental findings indicated that B10 cells possessed a protective role in active SLE especially LN, and the kidney might be the preferential target tissue for these cells in this disease.

Glomerular endothelial cell (GEC) activation followed by functional disorders is the main reason for the glomerular damage of $\operatorname{LN}[21,22]$. It has been reported that the expression 


\section{Cellular Physiology Cell Physiol Biochem 2015;36:2161-2169 \begin{tabular}{ll|l} 
and Biochemistry 1159/000430182 & $\begin{array}{l}\text { D 2015 S. Karger AG, Basel } \\
\text { Published online: July 21, } 2015\end{array}$ \\
\cline { 2 - 3 } & www.karger.com/cpb
\end{tabular} \\ Yu et al.: B10 Cells Inhibit Glomerular Endothelial Cell Activation}

of the adhesion molecules CD54 and CD106 by endothelial cells enhanced obviously in LN, both of which were up-regulated by P38 phosphorylation and down-regulated by the suppressor of cytokine secretion 3 (SOCS3) signal pathways respectively, accelerating GEC activation and injuries through attracting proinflammatory cells infiltration [23-26]. In this experiment, the glomerular damages were alleviated markedly in LN mice after being transferred with B10 cells, together with the decreased expressions of CD54 and CD106 on GEC, the elevated expression of SCOS3 and the depressed P38 phosphorylation in glomeruli. This suggested that B10 cells could attenuate GEC activation by inhibiting CD54 and CD106 expressions, ameliorating the progression of LN.

As the inflammatory cytokines and the autoantibody against DNA have been shown to be capable of directly inducing CD54 and CD106 expressions [27, 28], we have ever speculated that B10 cells might reduce the production of those two adhesion molecules by secreting anti-inflammatory cytokine IL-10, which was based on several studies taking IL-10 as the primary effector molecule of B10 cells. Unexpectedly, in B10 cells transferred LN mice, although the circulating TNF- $\alpha$ and IFN- $\gamma$ levels were decreased, accompanied by the decline of anti-dsDNA autoantibodies, the serum IL-10 levels were not changed with the increase of B10 cells. These data implied that B10 cells could restrain CD54/CD106-mediated GEC injuries by suppressing the TNF- $\alpha$, IFN- $\gamma$ and the pathogenic autoantibodies production. IL10 secreting from B cell might not regulate the autoimmunity in MRL/lpr SLE mice. Thus, we considered that IL-10 might be a marker but not the main effect molecule for B10 cells, and the other mechanisms of B10 cell repressing the TNF- $\alpha$, IFN- $\gamma$ and the pathogenic autoantibodies production needed our further exploration. In this study, although we proved that B10 cells could inhibit glomerular endothelial cell activation in vivo, the experiments of B10 and glomerular endothelial cell co-culture should be developed in vitro. After trying many times, we found that the primary glomerular endothelial cell could be viable for 48 hours if co-cultured with B cells. The acquisition of the glomerular endothelial cell line might achieve this. Additionally, the biology of B10 cells locally infiltrated into the kidney also needed further exploration.

\section{Disclosure Statement}

None declared.

\section{Acknowledgements}

This work was supported by the National Natural Science Foundation of China (81100158, 81470502, and 81400283).

\section{References}

1 Bagavant H, Fu SM: Pathogenesis of kidney disease in systemic lupus erythematosus. Curr Opin Rheumatol 2009;21:489-494.

2 Faurschou M, Dreyer L, Kamper AL, Starklint H, Jacobsen S: Long-term mortality and renal outcome in a cohort of 100 patients with lupus nephritis. Arthritis Care Res (Hoboken) 2010;62:873-880.

3 Ortega LM, Schultz DR, Lenz O, Pardo V, Contreras GN: Review: Lupus nephritis: pathologic features, epidemiology and a guide to therapeutic decisions. Lupus 2010;19:557-574.

4 Han Y, Zeng F, Tan G, Yang C, Tang H, Luo Y, Feng J, Xiong H, Guo Q: Hydrogen sulfide inhibits abnormal proliferation of lymphocytes via AKT/GSK3 $\beta$ signal pathway in systemic lupus erythematosus patients. Cell Physiol Biochem 2013;31:795-804.

5 Lipsky PE: Systemic lupus erythematosus: an autoimmune disease of B cell hyperactivity. Nat Immunol 2001;2:764-766.

6 Ivanova VV, Khaiboullina SF, Cherenkova EE, Martynova EV, Nevzorova TA, Kunst MA, Sibgatullin TB, Maksudova AN, Oliveira PJ, Lombardi VC, Palotás A, Rizvanov AA: Differential immuno-reactivity to 


\section{Cellular Physiology Cell Physiol Biochem 2015;36:2161-2169 \begin{tabular}{ll|l} 
and Biochemistry & $\begin{array}{l}\text { DOI: 10.1159/000430182 } \\
\text { Published online: July 21, } 2015\end{array}$ & $\begin{array}{l}\text { C 2015 S. Karger AG, Basel } \\
\text { www.karger.com/cpb }\end{array}$ \\
\hline
\end{tabular} \\ Yu et al.: B10 Cells Inhibit Glomerular Endothelial Cell Activation}

genomic DNA, RNA and mitochondrial DNA is associated with auto-immunity. Cell Physiol Biochem 2014;34:2200-2208.

7 Chan O, Shlomchik MJ: A new role for B cells in systemic autoimmunity: B cells promote spontaneous T cell activation in MRL-lpr/lpr mice. J Immunol 1998;160:51-59.

8 Donderski R, Szczepanek J, Domagalski K, Tretyn A, Korenkiewicz J, Marszałek A, Szymański A, Wolski Z, Odrowąż-Sypniewska G, Manitius J: Analysis of relative expression level of VEGF (vascular endothelial growth factor ), HIF-1 $\alpha$ ( hypoxia inducible factor $1 \alpha$ ) and CTGF ( connective tissue growth factor) genes in chronic glomerulonephritis (CGN) patients. Kidney Blood Press Res 2013;38:83-91.

9 Wang YY, Zhang L, Zhao PW, Ma L, Li C, Zou HB, Jiang YF: Functional implications of regulatory B cells in human IgA nephropathy. Scand J Immunol 2014;79:51-60.

10 Watanabe R, Ishiura N, Nakashima H, Kuwano Y, Okochi H, Tamaki K, Sato S, Tedder TF, Fujimoto M: Regulatory B cells (B10 cells) have a suppressive role in murine lupus: CD19 and B10 cell deficiency exacerbates systemic autoimmunity. J Immunol 2010;184:4801-4809.

11 Haas KM, Watanabe R, Matsushita T, Nakashima H, Ishiura N, Okochi H, Fujimoto M, Tedder TF: Protective and pathogenic roles for B cells during systemic autoimmunity in NZB/W F1 mice. J Immunol 2010;184:4789-4800.

12 Teichmann LL1, Kashgarian M, Weaver CT, Roers A, Müller W, Shlomchik MJ: B cell-derived IL-10 does not regulate spontaneous systemic autoimmunity in MRL.Fas(lpr) mice.J Immunol 2012;188:678-685.

13 Tan EM, Cohen AS, Fries JF, Masi AT, McShane DJ, Rothfield NF, Schaller JG, Talal N, Winchester RJ: The 1982 revised criteria for the classification of systemic lupus erythematosus. Arthritis Rheum 1982;25:12711277.

14 Bombardier C, Gladman DD, Urowitz MB, Caron D, Chang CH: Derivation of the SLEDAI. A disease activity index for lupus patients. The Committee on Prognosis Studies in SLE. Arthritis Rheum 1992;35:630-640.

15 Shlomchik MJ, Madaio MP, Ni D, Trounstein M, Huszar D: The role of B cells in lpr/lpr-induced autoimmunity. J Exp Med 1994;180:1295-1306.

16 D'Andrea DM, Coupaye-Gerard B, Kleyman TR, Foster MH, Madaio MP: Lupus autoantibodies interact directly with distinct glomerular and vascular cell surface antigens. Kidney Int 1996;49:1214-1221.

17 Blair PA, Noreña LY, Flores-Borja F, Rawlings DJ, Isenberg DA, Ehrenstein MR, Mauri C: CD19(+)CD24(hi) CD38(hi) B cells exhibit regulatory capacity in healthy individuals but are functionally impaired in systemic Lupus Erythematosus patients. Immunity 2010;32:129-140.

18 Yang X, Yang J, Chu Y, Xue Y, Xuan D, Zheng S, Zou H: T follicular helper cells and regulatory B cells dynamics in systemic lupus erythematosus. PLoS One 2014;9:e88441.

19 Howie AJ, Turhan N, Adu D: Powerful morphometric indicator of prognosis in lupus nephritis. QJM 2003;96:411-420.

20 Dall'Era M, Cisternas MG, Smilek DE, Straub L, Houssiau FA, Cervera R, Rovin BH, Mackay M: Predictors of long-term renal outcome in lupus nephritis trials: lessons learned from the euro-lupus nephritis cohort. Arthritis Rheumatol 2015;67:1305-1313.

21 Feliers D: Vascular endothelial growth factor as a prognostic marker of lupus nephritis. Kidney Int 2009;75:1251-1253.

22 Futrakul N, Panichakul T, Sirisinha S, Futrakul P, Siriviriyakul P: Glomerular endothelial dysfunction in chronic kidney disease. Ren Fail 2004;26:259-264.

23 Wuthrich RP, Jevnikar AM, Takei F, Glimcher LH, Kelley VE: Intercellular adhesion molecule-1 (ICAM-1) expression is upregulated in autoimmune murine lupus nephritis. Am J Pathol 1990;136:441-450.

24 Wuthrich RP: Vascular cell adhesion molecule-1 (VCAM-1) expression in murine lupus nephritis. Kidney Int 1992;42:903-914.

25 Stambe C, Nikolic-Paterson DJ, Hill PA, Dowling J, Atkins RC: p38 Mitogen-activated protein kinase activation and cell localization in human glomerulonephritis: correlation with renal injury. J Am Soc Nephrol 2004;15:326-336.

26 Gleissner CA, Zastrow A, Klingenberg R, Kluger MS, Konstandin M, Celik S, Haemmerling S, Shankar V, Giese T, Katus HA, Dengler TJ: IL-10 inhibits endothelium-dependent T cell costimulation by up-regulation of ILT3/4 in human vascular endothelial cells. Eur J Immunol 2007;37:177-192.

27 Lai KN, Leung JC, Lai KB, Wong KC, Lai CK: Upregulation of adhesion molecule expression on endothelial cells by anti-DNA autoantibodies in systemic lupus erythematosus. Clin Immunol Immunopathol 1996;81:229-238.

28 McHale JF, Harari OA, Marshall D, Haskard DO: TNF-alpha and IL-1 sequentially induce endothelial ICAM-1 and VCAM-1 expression in MRL/lpr lupus-prone mice. J Immunol 1999;163:3993-4000. 